\title{
UTJECAJ HIBRIDNIH VLAKANA NA MEHANIČKA SVOJSTVA BETONA
}

\section{THE EFFECT OF HYBRID FIBERS ON MECHANICAL PROPERTIES OF CONCRETE}

\author{
Natalija Bede*, Ivan Ušić*, Silvija Mrakovčić ${ }^{*}$
}

\begin{abstract}
Sažetak
U ovom je radu analizirano kako kombinacija različitih vrsta vlakana utječe na mehanička svojstva betona. U tu svrhu korištena su čelična vlakna u kombinaciji $s$ različitim volumnim udjelima polipropilenskih vlakana. Rezultati pokazuju da beton armiran samo čeličnim vlaknima ima najveću tlačnu čvrstoću, dok hibridni mikroarmirani betoni povećanjem udjela polipropilenskih vlakana pokazuju manje tlačne čvrstoće u odnosu na referentni beton. Nasuprot tome, hibridni beton s čeličnim vlaknima i volumnim udjelom polipropilenskih vlakana od 0,1\% ima najveću vlačnu čvrstoću savijanjem.
\end{abstract}

Ključne riječi: hibridni mikroarmirani beton, čelična vlakna, polipropilenska vlakna, tlačna čvrstoća, vlačna čvrstoća savijanjem

\begin{abstract}
In this paper, the effect of different type of fibers on mechanical properties of concrete was analyzed. For this purpose, steel fibers with different volume fraction of polypropylene fibers are used. The results show that concrete reinforced only with steel fibers gives the highest compressive strength, while the compressive strength of hybrid fiber reinforced concrete decreases with the increase of volume fraction of polypropylene fibers in comparison to the reference concrete. On the other hand, hybrid concrete with combination of steel fibers and $0.1 \%$ volume fraction of polypropylene fibers shows the highest bending tensile strength.
\end{abstract}

Key words: hybrid fiber reinforced concrete, steel fibers, polypropylene fibers, compressive strength, bending tensile strength

\footnotetext{
* Sveučilište u Rijeci, Građevinski fakultet, Radmile Matejčić 3, 51000 Rijeka E-mail: ivan.usic@student.uniri.hr, \{natalija.bede,silvija.mrakovcic\}@uniri.hr
} 


\section{Uvod}

U današnje se vrijeme u građevinarstvu sve češće koristi vlaknima mikroarmirani beton jer nudi raznovrsne mogućnosti primjene. Beton mikroarmiran vlaknima trenutno se najviše primjenjuju pri izradi tunelskih obloga, industrijskih podova, kolnih ploča mostova, utovarnih dokova, betonskih podloga te za sanaciju površinski oštećenih betona.

Mikroarmirani beton je kompozitni materijal koji u svom sastavu osim osnovnih sastojaka običnog betona: agregat, vezivo i voda, koji čine matricu betona, sadrži još i diskontinuirana vlakna [1]. Vlakna se dodaju svježem betonu tijekom procesa miješanja kako bi se omogućila njihova jednolika raspodjela u betonskoj matrici. Još od 1960. godine vlakna se dodaju cementnim kompozitima u svrhu poboljšanja njihovih osnovnih nedostataka, kao što je niska vlačna čvrstoća i vlačna čvrstoća savijanjem. U današnje vrijeme se za mikroarmiranje betona koriste različite vrste vlakana od čelika, polimera, ugljika, stakla i prirodnih materijala [1]. Svojstva betona mikroarmiranog vlaknima ovise o vrsti korištenih vlakana, količini, geometriji i gustoći te njihovoj orijentaciji i raspodjeli u matrici betona. Prema tome, svrha mikroarmiranog betona je dobivanje materijala koji ima poboljšana i fizikalna i mehanička svojstva u odnosu na normalni beton [2].

Mikroarmirani beton s dodatkom vlakana pokazuje znantno veću vlačnu čvrstoću i čvrstoću savijanjem, duktilnost, povećanje energije loma i žilavosti u odnosu na normalni beton. Vlakna se često dodaju betonima kako bi se kontroliralo pucanje betona uslijed plastičnog skupljanja ili sušenja. Također, neka vlakna doprinose i povećanju otpornosti na abraziju i trajnosti betona [3]. Polipropilenska i čelična vlakna su jedna od najčešće korištenih i istraživanih vlakana. Međutim, najnovija istraživanja su potvrdila da se primjenom hibridnih vlakana, odnosno kombinacijom dviju ili više vrsta vlakana, dobiva beton koji ima bolja mehanička svojstva od betona sa samo jednom vrstom vlakana [1-4]. Stoga je osnovni cilj rada bio istražiti na koji način kombinacija dviju različitih vrsta i omjera vlakana utječe na osnovna mehanička svojstva mikroarmiranog betona kao što su tlačna čvrstoća i vlačna čvrstoća savijanjem.

\section{2. Eksperimentalna istraživanja}

Provedena su vlastita eksperimentalna istraživnaja kako bi se ispitala osnovna svojstava svježeg i očvrsnulog mikroarmiranog betona [5]. Hibridne mješavine su spravljene $s$ dva različita tipa vlakana: čeličnim vlaknima koja su čvrsta i kruta te monofilamentnim polipropilenskim vlaknima koja su fleksibilna i duktilna. Sva su ispitivanja provedena 
prema Hrvatskim normama u Laboratoriju za materijale na Građevinskom fakultetu u Rijeci.

\subsection{Sastav betonskih mješavina}

Projektirano je pet različitih mješavina betona: referentna mješavina betona (bez vlakana) oznake REF i četiri mješavine mikroarmiranog betona $\mathrm{s}$ istim volumnim udjelom čeličnih vlakana $(2,5 \%)$ ali različitim udjelima polipropilenskih vlakana $(0 \%, 0,1 \%, 0,2 \%$ i $0,3 \%)$. Za oznaku mješavina mikroarmniranog betona uz oznaku o vrsti vlakna, slovo $\mathrm{S}$ za čelična vlakna i slova MF za monofilamentna polipropilenska vlakna, korišten je i broj koji označava volumni postotak vlakana u mješavini: S 2,5; S 2,5 - MF 0,1; S 2,5 MF 0,2; S 2,5 - MF 0,3 (Tablica 1).

Tablica 1. Oznake betonskih mješavina

\begin{tabular}{|c|c|c|}
\hline Oznaka mješavine & $\begin{array}{c}\text { Čelična } \\
\text { vlakna (\% vol) }\end{array}$ & $\begin{array}{c}\text { Monofilamentna } \\
\text { vlakna (\% vol) }\end{array}$ \\
\hline REF & 0 & 0 \\
\hline S 2,5 & 2,5 & 0 \\
\hline S 2,5 - MF 0,1 & 2,5 & 0,1 \\
\hline S $2,5-$ MF 0,2 & 2,5 & 0,2 \\
\hline S $2,5-$ MF 0,3 & 2,5 & 0,3 \\
\hline
\end{tabular}

Za spravljanje betonskih mješavina korišteni su sljedeći sastojci (Slika 1):

- bijeli cement CEM I 52,5R gustoće $3,04 \mathrm{~g} / \mathrm{cm}^{3}$

- silicijska prašina gustoće $2,18 \mathrm{~g} / \mathrm{cm}^{3}$

- voda iz gradskog vodovoda

- superplastifikator gustoće $1,04 \mathrm{~g} / \mathrm{cm}^{3}$

- stabilizator gustoće $1,01 \mathrm{~g} / \mathrm{cm}^{3}$

- agregat: drobljeni vapnenac frakcije 0-2 $\mathrm{mm}$, gustoće $2,88 \mathrm{~g} / \mathrm{cm}^{3}$

- kvarcni pijesak frakcije 0,1 - 0,6 mm, gustoće 2,62 g/ $\mathrm{cm}^{3}$

- čelična vlakna $13 / 0,2 \mathrm{~mm}$, gustoće $7,80 \mathrm{~g} / \mathrm{cm}^{3}$

- polimerna monofilamentna vlakna $12 \mathrm{~mm}$, gustoće $0,91 \mathrm{~g} / \mathrm{cm}^{3}$

Količine sastojaka za metar kubni betona za svaku od navedenih pet mješavina prikazane su u Tablici 2. Količine cementa, silicijske prašine, superplastifikatora i stabilizatora te vodovezivni omjer držani su konstantnima u svim mješavinama. 


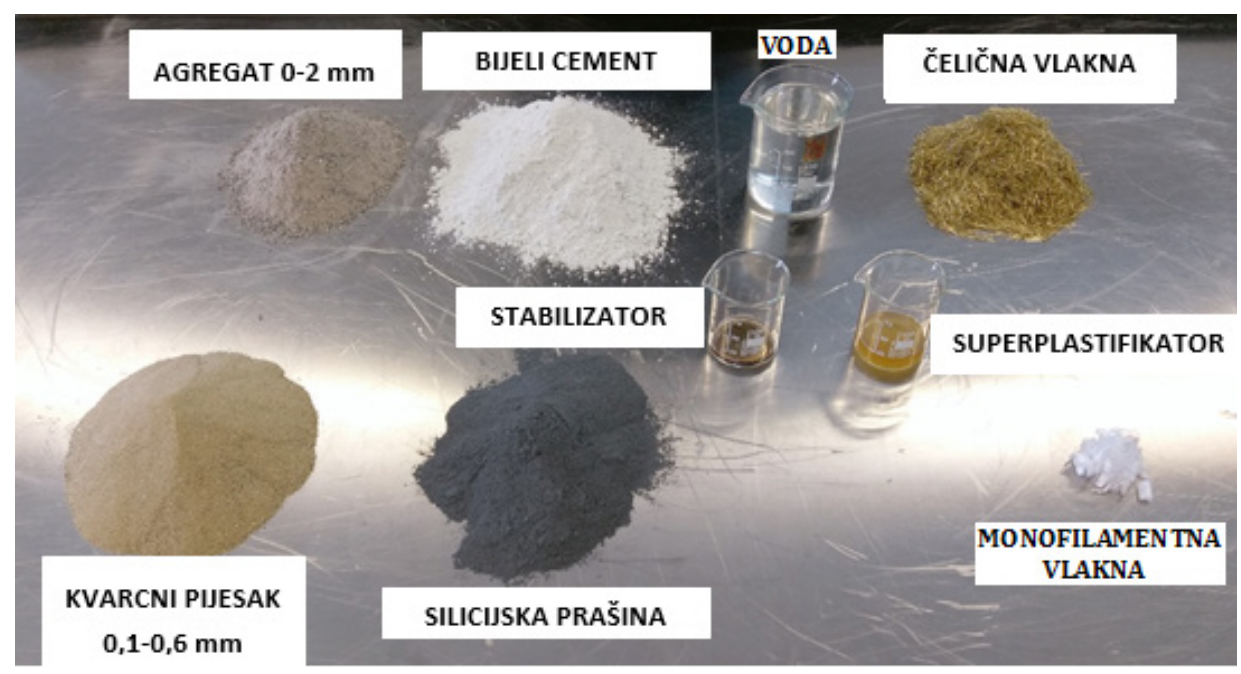

Slika 1. Sastavne komponente betonskih mješavina

Tablica 2. Količine sastojaka betonskih mješavina za $1 \mathrm{~m}^{3}$

\begin{tabular}{|c|c|c|c|c|c|}
\hline & \multicolumn{5}{|c|}{ OZNAKA MJEŠAVINE } \\
\hline SASTOJCI & REF & S 2,5 & S $2,5-\mathrm{MF} 0,1$ & S $2,5-\mathrm{MF} 0,2$ & S $2,5-\mathrm{MF} 0,3$ \\
\hline Cement (kg) & 640 & 640 & 640 & 640 & 640 \\
\hline $\begin{array}{c}\text { Silicijska prašina } \\
\text { (kg) }\end{array}$ & 160 & 160 & 160 & 160 & 160 \\
\hline Voda (l) & 256 & 255 & 255 & 255 & 255 \\
\hline $\begin{array}{l}\text { Superplastifikator } \\
\text { (kg) }\end{array}$ & 20 & 20 & 20 & 20 & 20 \\
\hline Stabilizator (kg) & 4,8 & 4,8 & 4,8 & 4,8 & 4,8 \\
\hline $\begin{array}{c}\text { Agregat } 0-2 \mathrm{~mm} \\
(\mathrm{~kg})\end{array}$ & 614 & 593 & 591 & 590 & 588 \\
\hline $\begin{array}{l}\text { Kvarcni pijesak } \\
0,1-0,6 \mathrm{~mm}(\mathrm{~kg})\end{array}$ & 560 & 540 & 539 & 537 & 536 \\
\hline $\begin{array}{c}\text { Čelična vlakna } \\
(\mathrm{kg})\end{array}$ & 0 & 117 & 117 & 117 & 117 \\
\hline $\begin{array}{c}\text { Monofilamentna } \\
\text { vlakna }(\mathrm{kg})\end{array}$ & 0 & 0 & 0,91 & 1,82 & 2,73 \\
\hline Vodovezivni omjer & 0,3 & 0,3 & 0,3 & 0,3 & 0,3 \\
\hline
\end{tabular}




\subsection{Izrada mješavina i ugradnja}

Za miješanje betona korištena je laboratorijska mješalica maksimalne zapremine 150 litara. Doziranje sastavnih materijala i procedura miješanja jedna je od najvažnijih faza u proizvodnji mikroarmiranog betona. U bubanj mješalice najprije su ubačeni agregat, kvarcni pijesak, silicijska prašina i polipropilenska vlakna, ukoliko se dodaju mješavini, te je provedeno suho miješanje u trajanju od 5 minuta. Nakon toga dodan je cement te je miješanje nastavljeno idućih 5 minuta. Zatim je dodano $80 \%$ vode i promiješano je još 2,5 minute. U slijedeće 2,5 minute dodano je još preostalih $20 \%$ vode s aditivima. Čelična vlakna su dodavana u rotirajući bubanj mješalice postupno i ravnomjerno kroz idućih 5 minuta [5].

Svježi beton (Slika 2) je u kalupe ugrađivan u tri sloja, pri čemu je svaki sloj zbijan pomoću stolnog vibratora. Ovaj način ugradnje je primijenjen kako bi se svježi beton što bolje rasporedio po kalupu i oslobodio zarobljenog zraka. Za svaku je mješavinu izrađeno šest uzoraka kocki brida $150 \mathrm{~mm}$ za ispitivanje tlačne čvrstoće, devet uzoraka prizmi dimenzija 100 $\mathrm{mm} \times 100 \mathrm{~mm} \times 400 \mathrm{~mm}$ za ispitivanje vlačne čvrstoće savijanjem te tri uzorka valjka visine $200 \mathrm{~mm}$ i promjera $100 \mathrm{~mm}$ za određivanje gustoće i sadržaja pora (Slika 3). Nakon 24 sata uzorci su izvađeni iz kalupa te njegovani u vodi temperature $20 \pm 2{ }^{\circ} \mathrm{C}$ do dana ispitivanja.

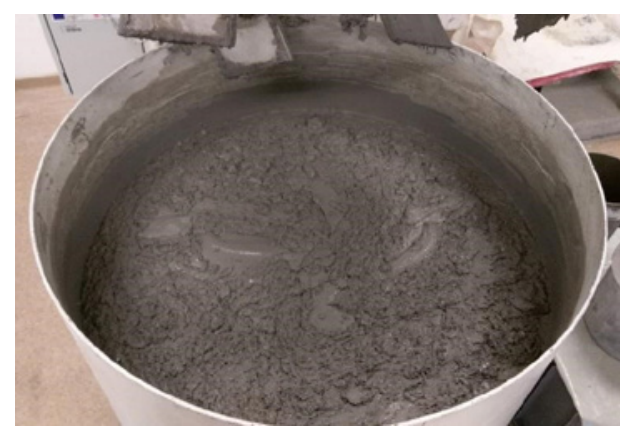

Slika 2. Svježi beton

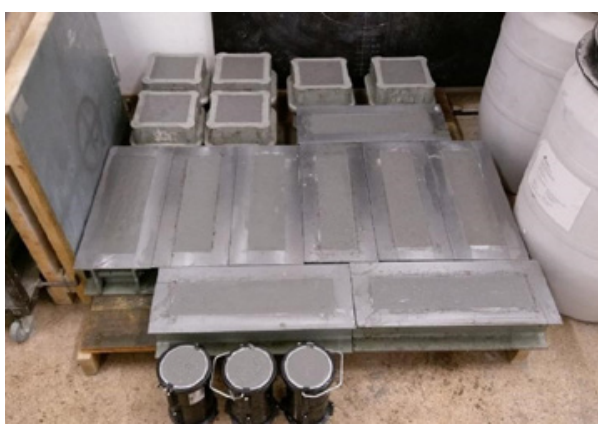

Slika 3. Beton ugrađen u kalupe

\subsection{Metode ispitivanja svježeg betona}

Odmah po završetku miješanja svježeg betona a prije ugradnje u kalupe ispitana je gustoća. Kako bi se usporedila obradivost referentne mješavine i mješavina s različitim volumnim udjelima vlakana provedeno je i ispitivanje konzistencije metodom rasprostiranja. Gustoća svježeg betona ispitana je prema normi HRN EN 12350-6 [6]. Ispitivanje konzistencije rasprostiranjem provedeno je prema normi HRN EN 12350-5 [7]. 


\subsection{Metode ispitivanja očvrslog betona}

Na očvrsnulom je betonu ispitana gustoća, sadržaj pora, te tlačna čvrstoća i vlačna čvrstoća savijanjem. Svojstva očvrslog betona ispitana su na uzorcima koji su 28 dana njegovani u vodi temperature $20 \pm 2{ }^{\circ} \mathrm{C}$. Uzorci su izvađeni iz bazena za njegovanje neposredno prije samog ispitivanja.

\subsubsection{Gustoća i sadržaj pora}

Gustoća i sadržaj pora u očvrsnulom betonu ispitani su na tri uzorka valjka promjera $100 \mathrm{~mm}$ i visine $50 \mathrm{~mm}$ za svaku mješavinu. Gustoća očvrsnulog betona ispitana je prema normi HRN EN 12390-7 [8]. Detaljniji opis postupka ispitivanja može se pronaći u [5].

\subsubsection{Tlačna čvrstoća}

Ispitivanje tlačne čvrstoće provedeno je na uzorcima oblika kocke brida $150 \mathrm{~mm}$ prema normi HRN EN 12390-3 [9]. Ukupno je ispitano 30 kocki, odnosno šest kocki po mješavini. Ispitivanje je provedeno na hidrauličnoj preši za ispitivanje tlačne čvrstoće marke Controls, tip C56Z000, maksimalnog kapaciteta $3000 \mathrm{KN}$ (Slika 4). Za svaki uzorak je analiziran oblik sloma, zabilježena maksimalna sila pri slomu $F$ te izračunata tlačna čvrstoća prema izrazu danom u [9].
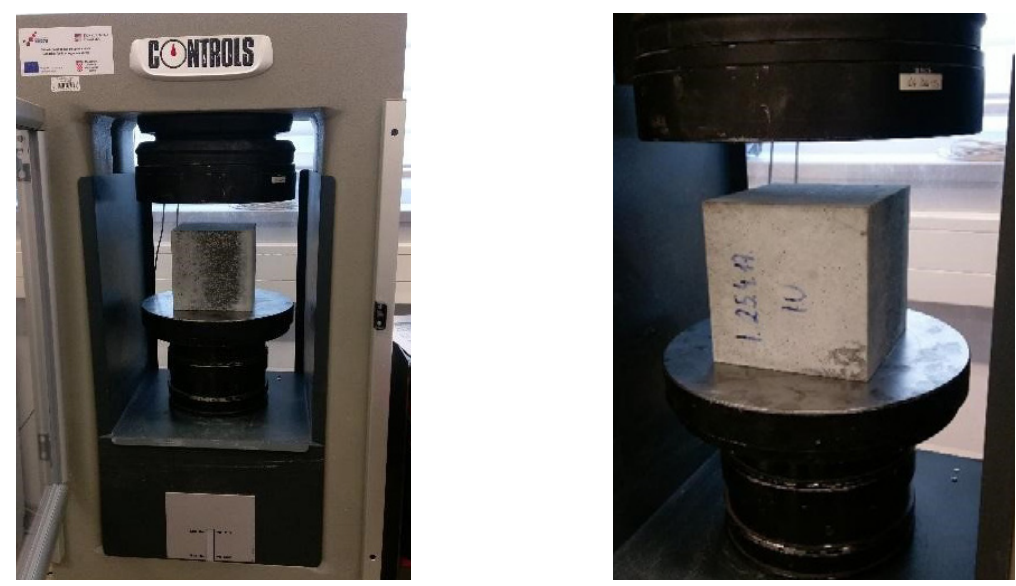

Slika 4. Ispitivanje tlačne čvrstoće

\subsubsection{Vlačna čvrstoće savijanjem}

Ispitivanje vlačne čvrstoće savijanjem provedeno je na prizmama dimenzija $100 \mathrm{~mm} \times 100 \mathrm{~mm} \times 400 \mathrm{~mm}$. Prema normi ASTM C1609/ C1609M - 19 [10] propisana je minimalna duljina uzorka od $3 \times b$, gdje je 
$b$ širina poprečnog presjeka. Preporuka norme ASTM C1609/C1609M - 19 [10] i HRN EN 14651 [11] je da se na uzorcima prizmi zareže zarez s donje strane u zoni pojave vlačnog naprezanja kako bi se iniciralo mjesto pojave pukotine. Međutim, na ispitivanim uzorcima nije bio cilj unaprijed odrediti mjesto nastanka pukotine, već je promatrano gdje će se pojaviti pukotine uslijed opterećenja.

Sveukupno je ispitano 45 prizmi, odnosno devet uzoraka po svakoj mješavini. Ispitivanje je provedeno pomoću uređaja marke Controls, model 50-C1601/FR, maksimalnog kapaciteta $300 \mathrm{kN}$. Pri ispitivanju se uzorak opterećivao na savijanje kontrolom pomaka s jednom koncentriranom silom na sredini raspona prizme. Brzina nanošenja opterećenja određena je eksperimentalno, tako da se zadovolji uvjet da pojava prve pukotine bude između 30 i $60 \mathrm{~s}$ od početka ispitivanja [10] te da se maksimalna sila $F$ postigne u vremenu od 3 do 5 minuta od početka ispitivanja (statičko ispitivanje). Za vrijeme ispitivanja mjeren je pomak pomoću dva LVDT uređaja marke Controls, model 82-P0311/CC, s maksimalnim mjernim pomakom $10 \mathrm{~mm}$. LVDT uređaji su postavljeni s prednje i stražnje strane uzorka na istoj udaljenosti od sredine raspona prizme kako bi se kod obrade rezultata izračunom srednje vrijednosti dobili pomaci na sredini raspona prizme. Uređaj, mjerni instrumenti i način ispitivanja prikazani su na Slici 5. Za svaki ispitani uzorak zabilježena je krivulja sila-pomak do sveukupnog vremena od $1800 \mathrm{~s}$ (30 min), oblik sloma te pojava prve pukotine i intenzitet maksimalne sile. Vlačna čvrstoća na savijanje određena je prema izrazu danom u [11].

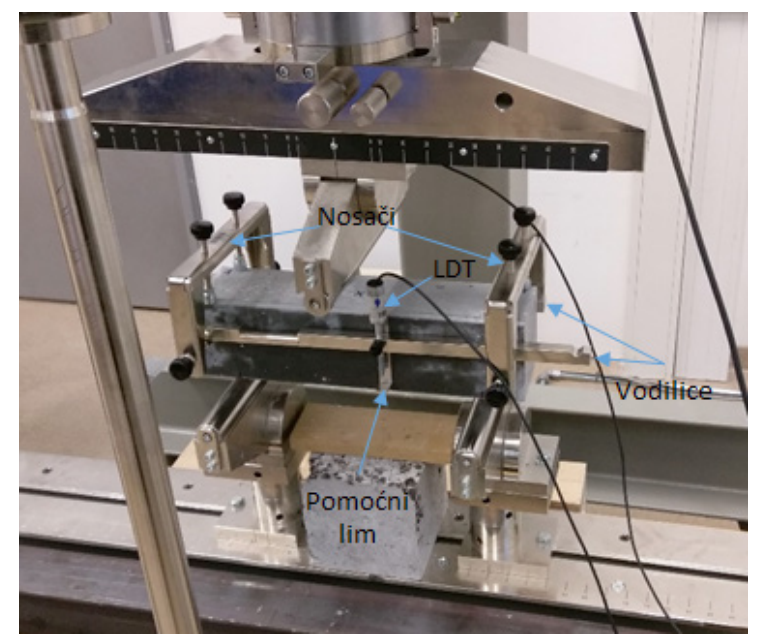

Slika 5. Ispitivanje vlačne čvrstoće savijanjem kontrolom pomaka 


\section{Rezultati i analiza}

Cilj je ovog istraživanja bio procijeniti utjecaj hibridnih vlakana $\mathrm{u}$ mikroarmiranom betonu na osnovna mehanička svojstva. Stoga su dobiveni rezultati ispitivanja uspoređeni i s rezultatima ispitivanja referentnog betona. Prvo su prikazani rezultati ispitivanja svježeg betona. Nakon toga dana je usporedba rezultata ispitivanja gustoće, sadržaja pora te tlačne i vlačne čvrstoće pri savijanju. Rezultati ispitivanja u obliku dijagrama silapomak objavit će se u sljedećem radu.

\subsection{Rezultati ispitivanja svježeg betona}

Rezultati ispitivanja svježeg betona prikazani su u Tablici 3. Na osnovi rezultata ispitivanja ustanovljeno je da mješavina $s$ čeličnim vlaknima oznake S 2,5 ima najveću gustoću u svježem stanju u usporedbi s ostalim mješavinama. U odnosu na referentnu mješavinu gustoća je veća za samo $7 \%$. Nadalje, hibridne mješavine s povećanjem udjela polipropilenskih vlakana pokazuju trend smanjenja gustoće. Smanjenje gustoće povećanjem polipropilenskih vlakana može se objasniti nejednolikom raspodjelom vlakana u betonskoj matrici, odnosno povećanjem udjela zraka.

$S$ obzirom na izmjerene vrijednosti promjera rasprostiranja vidljivo je da sve mješavine pokazuju vrlo sličnu obradljivost. Međutim, uočen je lagani porast obradljivosti povećanjem volumnog udjela vlakana: mješavina S 2,5 - MF 0,3 je pokazala najveću, a REF mješavina najmanju vrijednost rasprostiranja. Sve mješavine su svrstane u razrede rasprostiranja F1 osim mješavine s najvećim udjelom vlakana $S$ 2,5 - MF 0,3 koja pripada razredu F2. Dobiveni rezultati nisu u skladu s očekivanjima, međutim, može biti da privlačne sile između matrice i vlakana slabe kako raste volumni udio vlakana, što dovodi do povećanja promjera rasprostiranja.

Tablica 3. Rezultati ispitivanja svježeg betona

\begin{tabular}{|c|c|c|c|c|c|}
\hline Oznaka mješavine & REF & S 2,5 & S 2,5 - MF 0,1 & S 2,5 - MF 0,2 & S 2,5 - MF 0,3 \\
\hline Gustoća $\left[\mathrm{kg} / \mathrm{m}^{3}\right]$ & 2135 & 2282 & 2151 & 2126 & 2094 \\
\hline $\begin{array}{c}\text { Promjer } \\
\text { rasprostiranja } \\
{[\mathrm{mm}]}\end{array}$ & 280 & 300 & 340 & 340 & 350 \\
\hline $\begin{array}{c}\text { Razred } \\
\text { rasprostiranja }\end{array}$ & $\mathrm{F} 1$ & $\mathrm{~F} 1$ & $\mathrm{~F} 1$ & $\mathrm{~F} 1$ & F2 \\
\hline
\end{tabular}




\subsection{Rezultati ispitivanje očvrslog betona}

\subsubsection{Gustoća i sadržaj pora}

Srednje vrijednosti ispitivanja gustoće i sadržaja pora u očvrsnulom betonu za svaku mješavinu dane su u Tablici 4. Rezultati ispitivanja gustoće pokazuju nešto veće vrijednosti od rezultata dobivenih ispitivanjem svježeg betona, za $6 \%$ do $12 \%$, međutim, prate isti trend kao i rezultati dobiveni za svježi beton. Sukladno tome, mješavina S 2,5 ima najveću gustoću (u odnosu na referentnu mješavinu gustoća je veća za $8 \%$ ) ali i ujedno najmanji udio pora. Kao i kod ispitivanja gustoće svježeg betona, iako je razlika gustoća hibridnih mješavina vrlo malena, do najviše $3,5 \%$, hibridne mješavine pokazuju trend smanjenja gustoće povećanjem udjela vlakana. Veći udio vlakana u hibridnim mješavinama otežao je ugradnju betona, što je u konačnici dovelo i do malog povećanja udjela zraka odnosno poroznosti.

Tablica 4. Rezultati ispitivanja gustoće i sadržaja pora u očvrsnulom betonu

\begin{tabular}{|c|c|c|c|c|c|}
\hline Oznaka mješavine & REF & S 2,5 & S 2,5 - MF 0,1 & S 2,5 - MF 0,2 & S 2,5 - MF 0,3 \\
\hline Gustoća [kg/m $\left.{ }^{3}\right]$ & 2260 & 2440 & 2400 & 2390 & 2320 \\
\hline Sadržaj pora [\%] & 4,3 & 3,7 & 4,1 & 4,4 & 4,6 \\
\hline
\end{tabular}

\subsubsection{Tlačna čvrstoća}

Na Slici 6 prikazani su rezultati ispitivanja za svih šest uzoraka po mješavini zajedno sa srednjom vrijednošću tlačne čvrstoće betona za svaku mješavinu. Srednja vrijednost tlačne čvrstoće dobivena na temelju rezultata ispitivanja kreće se u rasponu od $71 \mathrm{MPa}$ do $101 \mathrm{MPa}$ pa se može zaključiti da se radi o betonu visokih čvrstoća. Najveća tlačna čvrstoća postignuta je za mješavinu S 2,5 koja sadrži samo jednu vrstu vlakana - čelična vlakna. U odnosu na mješavinu referentnog betona tlačna čvrstoća je povećana za $17 \%$. Nasuprot tome, kod hibridnih mješavina je uočen trend smanjenja tlačne čvrstoće povećanjem udjela polipropilenskih vlakana. U odnosu na mješavinu S 2,5, smanjenje tlačne čvrstoće redom iznosi 20\%, 22\% i 41\%, a u odnosu na referentnu mješavinu 3\%, 4\% i 21\%. Ti rezultati su u skladu s rezultatima ispitivanja koje su proveli Selvi i Thandavamoorthy [3]. Smanjenje tlačne čvrstoće povećanjem udjela polipropilenski vlakana može se objasniti povećanjem količine zraka u mješavini zbog otežane ugradnje i nejednolike distribucije vlakana. 


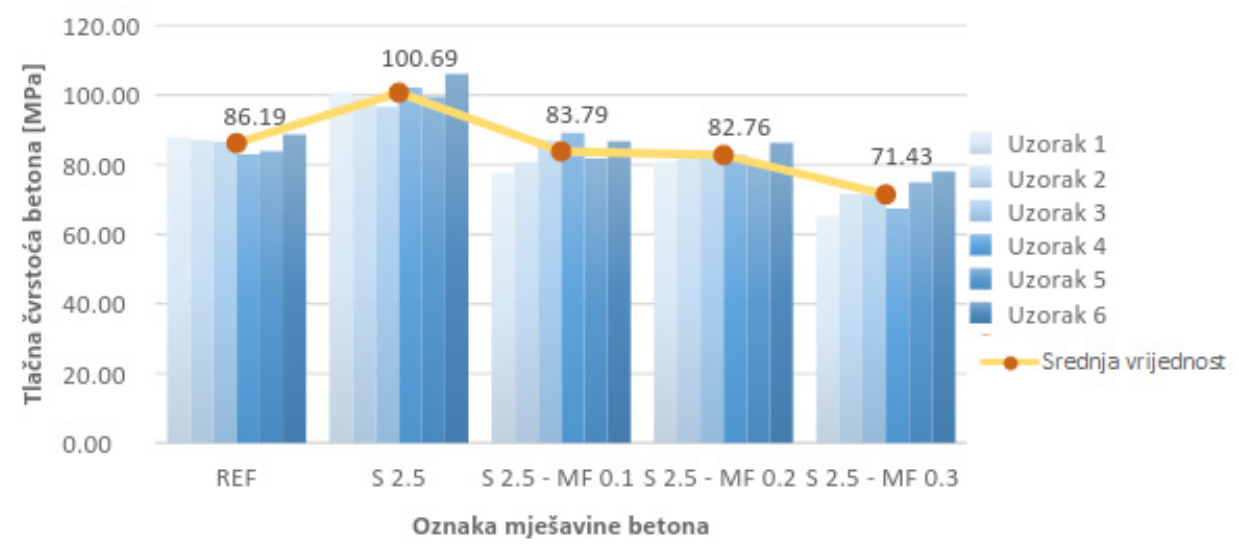

Slika 6. Tlačna čvrstoća

Na Slici 7 prikazan je tipični oblik sloma za referentnu mješavine betona REF (lijevo) i mješavinu betona s vlaknima oznake S 2,5 (desno). Kod referentnog uzorka pojavio se krti lom, a kod mješavina koje sadrže vlakna pojavilo se nekoliko sitnih pukotina, no zadržana je strukturna cjelovitost uzorka.
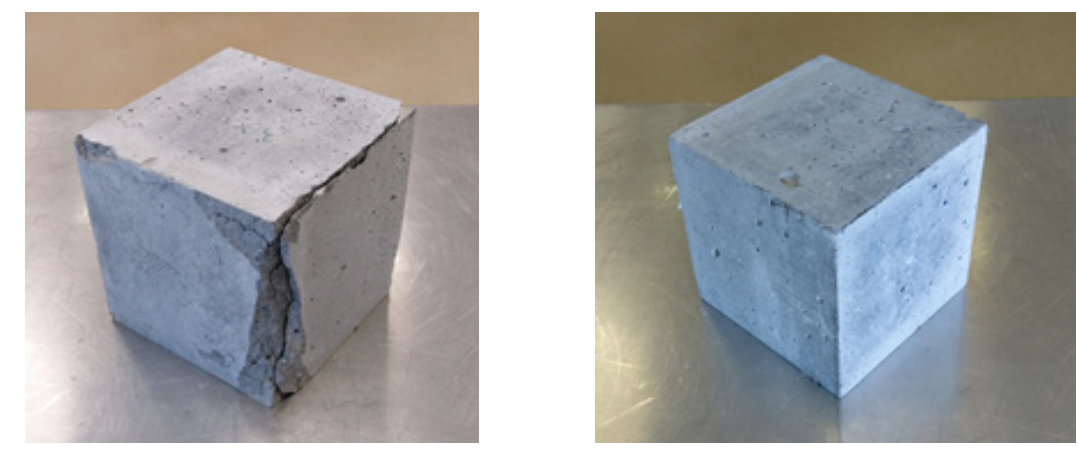

Slika 7. Oblik sloma pri ispitivanju na tlak: REF mješavina (lijevo), mješavina $S 2,5$ (desno)

\subsubsection{Korelacija između gustoće i tlačne čvrstoće}

Odnos tlačne čvrstoće i gustoće betona ispitnih uzoraka prikazan je na Slici 8. Iz rezultata se može primijetiti da postoji čvrsta veza između tlačne čvrstoće i gustoće: koeficijent korelacije $\mathrm{R}^{2}=0,84$. Za mješavinu $\mathrm{S}$ 2,5 s najvećom gustoćom postignuta je i najveća tlačna čvrstoća. Mješavine s hibridnim vlaknima povećanjem udjela vlakana pokazuju smanjenje gustoće i tlačne čvrstoće. 


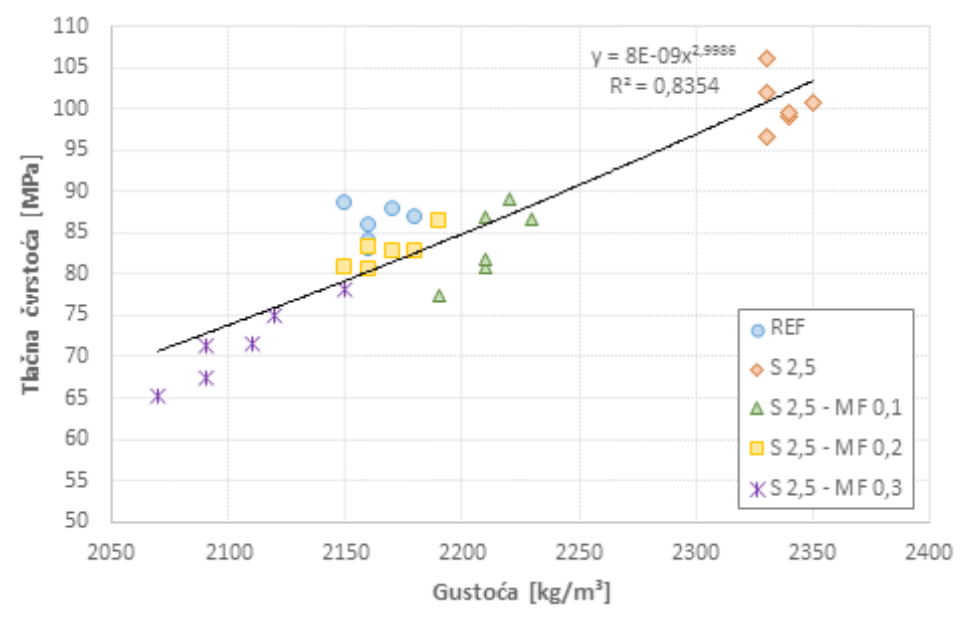

Slika 8. Odnos tlačne čvrstoće i gustoće očvrslog betona

\subsubsection{Vlačna čvrstoće savijanjem}

Rezultati ispitivanja vlačne čvrstoće savijanjem pojedinačnih uzoraka svake mješavine zajedno sa srednjom vrijednošću mješavine prikazani su dijagramom na Slici 9. Analizom dobivenih rezultata može se zaključiti da najveću čvrstoću na savijanje ima hibridna mješavina S 2,5 - MF 0,1 i ona iznosi 18,82 MPa. Kao što je i očekivano, srednja vrijednost vlačne čvrstoće betona za referentnu mješavinu je najmanja i iznosi 11,53 MPa. Dakle, u hibridnoj mješavini S 2,5 - MF 0,1 povećanje vlačne čvrstoće savijanjem u odnosu na referentnu mješavinu iznosi $63 \%$, odnosno $12 \%$ u odnosu na mješavinu sa samo jednom vrstom vlakana. Vrijednost vlačne čvrstoće betona savijanjem S 2,5 sa samo jednom vrstom vlakna je veća za $46 \%$ nego u referentnom betonu. Istovjetni trend u svom radu dali su Bošnjak i dr. [12].

Mješavina S 2,5 - MF 0,3 koja ima najveći udio polipropilenskih vlakana pokazuje najmanju čvrstoću na savijanje među hibridnim betonskim mješavinama i ona iznosi $13,67 \mathrm{MPa}$, odnosno, $38 \%$ manju čvrstoću od najveće izmjerene vrijednosti hibridne mješavine, a samo $18 \%$ veću od referentne mješavine. Dakle, povećanjem udjela polipropilenskih vlakna iznad $0,1 \%$ dolazi do smanjenja vlačne čvrstoće savijanjem. 


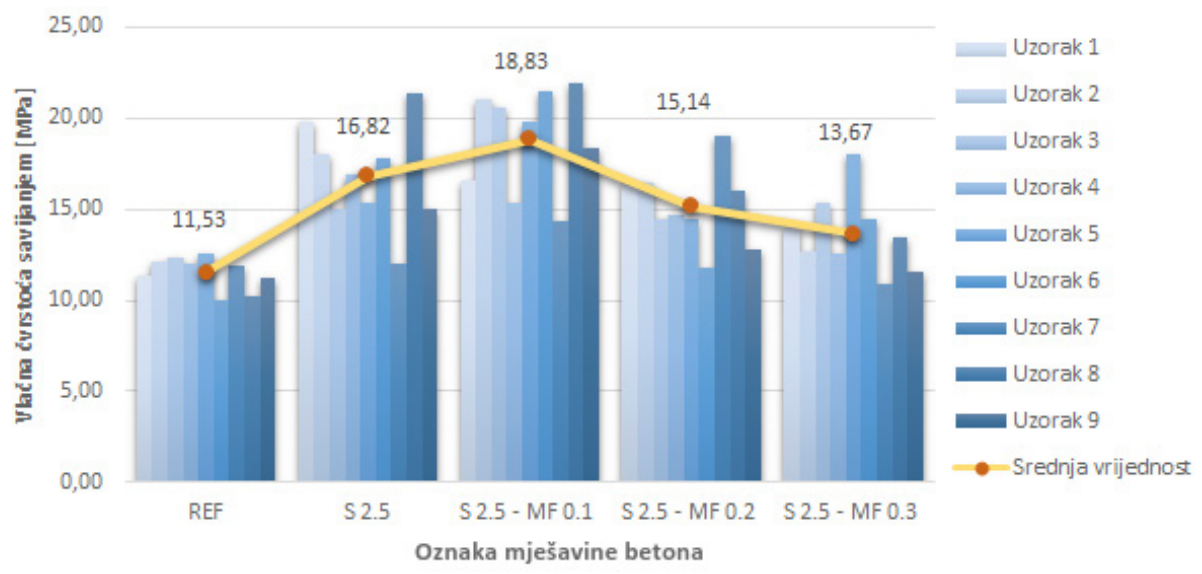

Slika 9. Vlačna čvrstoća savijanjem

Na Slici 10 prikazan je lom uzoraka referentne mješavine bez vlakana a na Slici 11 tipični oblik sloma uzoraka s vlaknima. Kod svih uzoraka s vlaknima ispitni uzorci pokazali su veliku žilavost (duktilnost) za razliku od običnog betona (REF mješavina) kod kojeg je vidljiva pojava izuzetno krtog loma. Za razliku od REF mješavine, kod ostalih mješavina koje su sadržavale ili samo čelična ili kombinaciju čeličnih i polipropilenskih vlakana u različitim postocima, tijekom ukupnog vremena ispitivanja nije došlo do potpunog sloma uzoraka (vidi Slika 11, lijevo). Kako bi se analizirana površina loma, neki su uzorci dodatno ispitivani do potpunog sloma. Kod tih uzoraka je uočeno potpuno čupanje čeličnih vlakana te pucanje polipropilenskih vlakana (vidi Slika 11, desno).
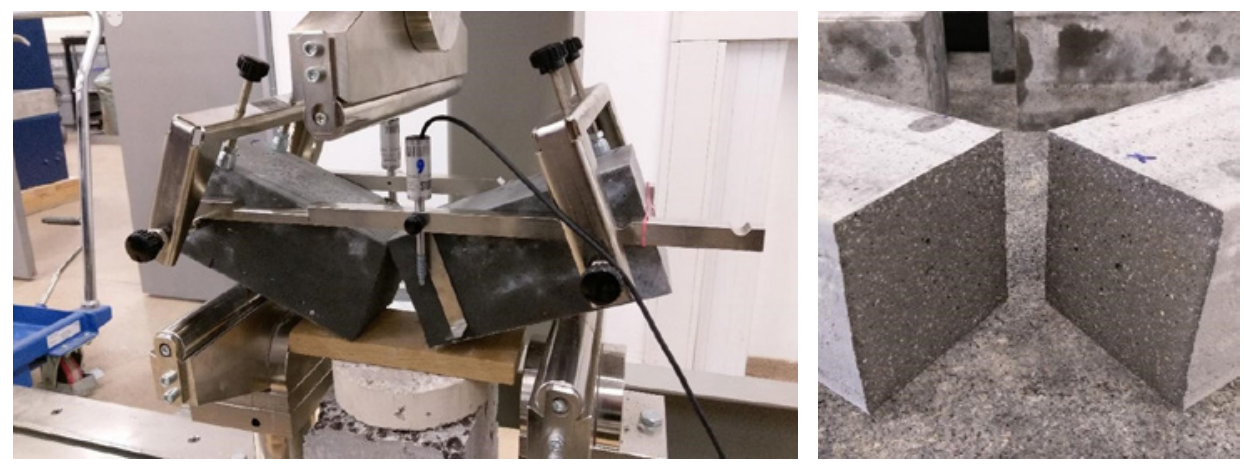

Slika 10. Ispitivanje na savijanje REF mješavina: oblik sloma (lijevo), površina sloma (desno) 

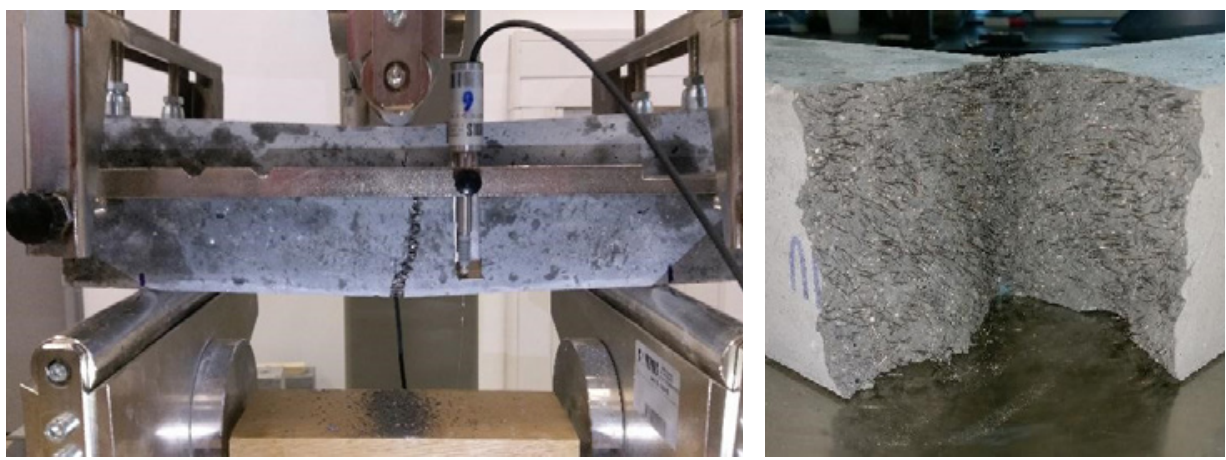

Slika 11. Ispitivanje na savijanje hibridna mješavina: oblik sloma (lijevo), površina sloma (desno)

\section{Zaključak}

Na temelju vlastitih eksperimentalnih rezultata zaključeno je slijedeće:

- Konzistencija rasprostiranjem se povećava udjelom vlakana bez obzira na to radi li se o jednoj vrsti ili više vrsta vlakana u mješavini.

- Gustoća očvrslog betona je veća od gustoće referentnog betona bez obzira radi li se samo o jednoj vrsti vlakana ili kombinaciji vlakana. Međutim, hibridne mješavine povećanjem udjela polipropilenskih vlakana pokazuju trend smanjenja gustoće. Najveći problem pri spravljanju betona armiranog vlaknima predstavlja postizanje jednolikog rasporeda vlakna u mješavini i sama ugradnja.

- Korištenje samo jedne vrste vlakana pozitivno utječe na povećanje tlačne čvrstoće betona. Dodatkom 2,5\% čeličnih vlakana povećana je tlačna čvrstoća betona za $17 \%$ u odnosu na referentnu mješavinu.

- Hibridna vlakna negativno utječu na tlačnu čvrstoću mikroarmiranog betona. U odnosu na referentnu mješavinu, povećanjem udjela polipropilenskih vlakana smanjuje se tlačna čvrstoća betona, od $3 \%$ do $21 \%$. U odnosu na mješavinu S 2,5 koja ima najveću čvrstoću i koja sadrži samo jednu vrstu vlakana, smanjenje tlačne čvrstoće redom iznosi 20\%, 22\% i 41\%.

- Između gustoće i tlačne čvrstoće betona postoji čvrsta korelacija. Povećanjem gustoće betona tlačna čvrstoća raste.

- Korištenje samo jedne vrste vlakana ili kombinacija dvije vrste vlakana pozitivno utječu na povećanje vlačne čvrstoće savijanjem. 
U odnosu na referentni beton, mješavine s vlaknima imaju veću vlačnu čvrstoću savijanjem. Dodatkom 2,5\% čeličnih vlakana povećana je vlačna čvrstoća betona savijanjem za $46 \%$ u odnosu na referentnu mješavinu. Dodavanjem hibridnih vlakana $\mathrm{s}$ volumnim udjelom od $0,1 \%$ polipropilenskih vlakana postiže se najveća vlačna čvrstoća savijanjem, $63 \%$ veća u odnosu na referentnu mješavinu, odnosno $12 \%$ veća u odnosu na mješavinu sa samo jednom vrstom vlakana. Međutim, svako daljnje povećanje udjela polipropilenskih vlakana smanjuje vlačnu čvrstoću savijanjem hibridnog betona.

- Potrebna je daljnja analiza rezultata eksperimentalnih ispitivanja dobivenih u obliku dijagrama sila-pomak kako bi se dobila šira slika o mehaničkim svojstvima betona mikroarmiranog hibridnim vlaknima.

- Na temelju ovog istraživanja je zaključeno da hibridna vlakana poboljšavaju neka osnovna mehanička svojstva kao što je vlačna čvrstoća betona savijanjem, ali pokazuju negativan utjecaj na tlačnu čvrstoću betona. Prema tome, da bi se postigla željena poboljšanja odgovarajućih svojstava očvrsnulog hibridnog betona treba izabrati odgovarajuću vrstu vlakana i optimalni volumni udio hibridnih vlakana.

Zahvala. Ovaj je članak rezultat rada u okviru projekta Razvoj istraživačke infrastrukture na Kampusu Sveučilišta u Rijeci (RC.2.2.060001) koji je financiran iz Europskog fonda za regionalni razvoj (EFRR) i Ministarstva znanosti, obrazovanja i sporta RH. Veliko hvala sljedećim tvrtkama na donaciji materijala: Holcim (Hrvatska) d.o.o., Sika d.o.o., BASF Croatia d.o.o. te DULY d.o.o.

\section{Literatura}

[1] Šahinagić-Isović, M. Posebne vrste betona: mikroarmirani beton. Univerzitet "Džemal Bijedić" u Mostaru. Građevinski fakultet. Mostar, 2015.

[2] Narayanan S., Muniasamy G., Kumar P.S., Ragul, K.A., Selvam, M. Past Investigations on Mechanical and Durability Properties of Hybrid Fiber Reinforced Concrete. International Journal of Civil Engineering and Technology (2019) 10(3),1-10.

[3] Tamil Selvi, M., Thandavamoorthy, T.S. Mechanical and Durability Properties of Steel and Polypropylene Fiber Reinfrced Concrete. International Journal of Earthand Scineces and Engineering, 2014, 696-703.

[4] Kanagavel,R., Kalidass, A. Mehanička svojstva hibridnog mikroarmiranog betona s miješanim cementom. Građevinar 69(2017) 1,1-10. 
[5] Ušić, I. Prodor klorida kroz mikroarmirani beton visoke čvrstoće. Diplomski rad. Građevinski fakultet, Sveučilište u Rijeci, Rijeka, 2017.

[6] HRN EN 12350-6:2009. Ispitivanje svježeg betona - 6. dio: Gustoća, Hrvatski zavod za norme, 2009.

[7] HRN EN 12350-5:2009. Ispitivanje svježega betona - 5. dio: Ispitivanje rasprostiranjem, Hrvatski zavod za norme, 2009.

[8] HRN EN 12390-7:2009. Ispitivanje očvrslog betona - 7. dio: Gustoća očvrslog betona, Hrvatski zavod za norme, 2009.

[9] HRN EN 12390-3:2009. Ispitivanje očvrslog betona - 3. dio: Tlačna čvrstoća ispitnih uzoraka, Hrvatski zavod za norme, 2009.

[10] ASTM C1609/C1609M-12. Standard Test Method for Flexural Performance of Fiber-Reinforced Concrete (Using Beam With Third-Point Loading), 2012.

[11] HRN EN 14651: Ispitna metoda za beton ojačan metalnim vlaknima Mjerenje savojne čvrstoće (granica proporcionalnosti (LOP), iznos ostatka, Hrvatski zavod za norme, 2008.

[12] Bošnjak, J., Sharma, A., Grauf, K. Mechanical Properties of Concrete with Steel and Polypropylene Fibers at Elevated Temperatures. Fibers 2019, 7(2), 9; 1-13, https://doi.org/10.3390/fib7020009 
